\title{
Youth and adult education in the municipality of Marília in the period 2009-2019
}

\section{A educação de jovens e adultos no município de Marília no período de 2009-2019}

\section{La educación de jóvenes y adultos en el municipio de Marília en el período 2009-2019}

\author{
Talita dos Santos Gonçalves ${ }^{1}$ iD , Claudia Pereira de Pádua Sabia ${ }^{1}$ iD \\ ${ }^{1}$ São Paulo State University, Marília, São Paulo, Brazil. \\ Corresponding author: \\ Claudia Pereira de Pádua Sabia \\ Email: mailto:claudia.sabia@unesp.br
}

How to cite: Gonçalves, T. S., \& Sabia, C. P. P. (2021). Youth and adult education in the municipality of Marília in the period 2009-2019. Revista Tempos e Espaços em Educação, 14(33), e16796.

http://dx.doi.org/10.20952/revtee.v14i33.16796

\begin{abstract}
The Youth and Adult Education (YAE) modality was established by the Law of Guidelines and Bases for National Education (LDBEN) in 1996. YAE is intended for people over 18 years of age who have not completed elementary and secondary education and this type of education it is the opportunity for them to continue or start schooling. The objective of the study was to identify how the offer of this modality is organized in the city of Marilia between 2009-2019 and to verify its characteristics, its possible advances and/or setbacks. The research had a Scientific Initiation grant from the Foundation for Research Support of the State of São Paulo (FAPESP). The methodology uses a qualitative approach and bibliographic and documentary research. The documentary research consisted of the National Education Plan (PNE 2014-2024) and the Municipal Education Plan (PME 2015-2025) and the Statistical Synopsis of the National Institute of Educational Studies and Research Anísio Teixeira (INEP). As a result, we identified a mismatch between the goals established in the PME (2015-2025) and the enrollments carried out in the YAE in the studied municipality, which have been decreasing sharply between 2009-2019. We also verified in the PPP of two surveyed schools, which both bring in their Teaching Plan for YAE, repetitive content and a language aimed at children, constituting an inadequate methodology for the target audience, mostly composed of adults and elderly people above 60 years old, disregarding the life context of its students, their trajectories and experiences, contrary to what Paulo Freire proposes in his method and adult literacy for "reading the word and reading the world".
\end{abstract}

Keywords: Illiteracy. Municipal Education Plan of Marília. National Education Plan. Public Policies for Youth and Adult Education (YAE). Right to education. 


\section{RESUMO}

A modalidade Educação de Jovens e Adultos (EJA) foi instituída pela Lei de Diretrizes e Bases da Educação Nacional (LDBEN) em 1996. A EJA é destinada às pessoas maiores de 18 anos que não concluíram os ensinos fundamental e médio e esta modalidade da educação é a oportunidade para que prossigam ou iniciem a escolaridade. $O$ objetivo do estudo foi identificar como é organizada a oferta desta modalidade no município de Marília entre 2009-2019 e verificar suas características, seus possíveis avanços e/ou retrocessos. A pesquisa contou com bolsa de IC da Fundação de Amparo à Pesquisa do estado de São Paulo (FAPESP). A metodologia utiliza a abordagem qualitativa e as pesquisas bibliográfica e documental. A pesquisa documental consistiu no Plano Nacional de Educação (PNE 2014-2024) e Plano Municipal de Educação (PME 2015-2025) e na Sinopse Estatística do Instituto Nacional de Estudos e Pesquisas Educacionais Anísio Teixeira (INEP). Como resultados, identificamos um descompasso entre as metas estabelecidas no PME (2015-2025) e as matrículas realizadas na EJA no município estudado que vêm diminuindo acentuadamente entre 2009-2019. Verificamos também no PPP de duas escolas pesquisadas, que ambas trazem em seu Plano de Ensino para a EJA, conteúdos repetitivos e uma linguagem direcionada às crianças, constituindo-se numa metodologia inadequada para o público-alvo, majoritariamente composto por adultos e idosos acima de 60 anos, desconsiderando o contexto de vida de seus educandos, suas trajetórias e vivências, contrário ao que propõe Paulo Freire em seu método e alfabetização de adultos para a "leitura da palavra e leitura do mundo".

Palavras-chave: Analfabetismo. Direito à Educação. Plano Municipal de Educação de Marília. Plano Nacional de Educação. Políticas Públicas para a Educação de Jovens e Adultos (EJA).

\section{RESUMEN}

La modalidad de Educación de Jóvenes y Adultos (EJA) fue establecida por la Ley de Lineamientos y Bases de la Educación Nacional (LDBEN) en 1996. EJA está destinada a personas mayores de 18 años que no hayan completado la educación primaria y secundaria y este tipo de educación. es la oportunidad para que continúen o comiencen sus estudios. El objetivo del estudio fue identificar cómo se organiza la oferta de esta modalidad en la ciudad de Marília entre 2009-2019 y verificar sus características, sus posibles avances y/o retrocesos. La investigación contó con una beca de Iniciación Científica de la Fundación de Apoyo a la Investigación del Estado de São Paulo (FAPESP). La metodología utiliza un enfoque cualitativo y una investigación bibliográfica y documental. La investigación documental consistió en el Plan Nacional de Educación (PNE 2014-2024) y el Plan Municipal de Educación (PME 2015-2025) y la Sinopsis Estadística del Instituto Nacional de Estudios e Investigaciones Educativas Anísio Teixeira (INEP). Como resultado, identificamos un desajuste entre las metas establecidas en el PME (2015-2025) y las matrículas realizadas en la EJA en el municipio estudiado, las cuales han venido disminuyendo drásticamente entre 2009-2019. También verificamos en el PPP de dos colegios encuestados, que ambos traen en su Plan Docente para EJA, contenidos repetitivos y un lenguaje dirigido a niños, constituyendo una metodología inadecuada para el público objetivo, compuesto mayoritariamente por adultos y ancianos mayores de 60 años, desconociendo el contexto de vida de sus alumnos, sus trayectorias y vivencias, contrario a lo que propone Paulo Freire en su método y alfabetización de adultos para "leer la palabra y leer el mundo".

Palabras clave: Analfabetismo. Derecho a la educación. Plan de Educación Municipal de Marília. Plan Nacional de Educación. Políticas Públicas de Educación de Jóvenes y Adultos (EJA).

\section{INTRODUCTION}

The problem of illiteracy in the country persists to this day, as it results from teaching aimed at the labor market, with methodologies that favor a small portion of the population (the dominant class). Because there is still a traditional view of teaching, many subjects are left out of education, 
since an education centered on the educator is elected, in which the historical context of their students is ignored, and thus, this education tends to fail in contributing to an integral development of the student. When we talk about Youth and Adult Education (YAE), it is an even more delicate situation, as we are dealing with individuals who did not have access to education at an appropriate age or had their educational process interrupted at some point in their lives and ended up facing situations such as contempt and social devaluation, having to overcome prejudices and challenges when entering other social spheres, in the labor market, for example, often remaining on the margins of society.

Therefore, we must treat YAE by enabling an education that gives light to its students, promotes their emancipation through clarifications and new/other learning and knowledge, always valuing the historical subject that is in front of us, as this also has knowledge acquired in their experiences in the relationship with the other. In this way, studying and understanding the role of public policies for YAE becomes fundamental for us to achieve quality education for these citizens, which meets their needs as they are entitled to.

The general objective of this work is to identify how the provision of YAE is organized in the city of Marília/SP based on the period from 2009 to 2019, being five years before the Municipal Education Plan - PME (2015-2025) and five years after its term.

For the qualitative approach research, a bibliographic survey was carried out covering the themes related to this research and authors who are reference in Youth and Adult Education. The documental research consisted of the analysis of the Pedagogical Political Project (PPP) of two researched schools that offer YAE for the initial years of Elementary School in the studied city. Official documents such as the Law of Guidelines and Bases of National Education (LDBEN, Portuguese initials), no 9394/1996 (Brasil, 1996), National Education Plan (PNE, Portuguese initials) (2014-2024) and Municipal Education Plan (PME, Portuguese initials) of the municipality of Marília (2015-2025).

For the development of this study, we organized ourselves as follows: initially, we present a historical retrospective of YAE in Brazil, demarcating the advances and setbacks present in the trajectory of this teaching modality up to the present day. Subsequently, we brought a brief contextualization of the municipality in which we discussed the history of YAE in the municipality, as well as a survey of schools that currently offer the teaching modality. Next, we present the analysis of the curricula in which we also carry out a discussion about the offer of YAE in Marilia/SP. In the next section, we present the YAE targets in both the National Education Plan and the Municipal Education Plan and enrollment data during the study period of this project, in which we also address the absolute and functional illiteracy rate in the municipality. Finally, based on all the notes, we elaborate the final considerations of the work bringing the main points discussed throughout this work, followed by the references.

\section{HISTORICAL RETROSPECTIVE OF YAE DEMARCATED BY ADVANCES AND SETBACKS}

The trajectory of YAE is made up of struggles and challenges since its beginnings in 1549, the year in which the Jesuits arrived in Brazil and realized that without literate the indigenous people it would not be possible to convert them to the Christian faith. According to Quaglio (1992), the Jesuit priests started teaching native adults to read and write, giving rise to the first adult educators in the country. With the expulsion of the Jesuits, which occurred in 1759 and, with the beginning of the empire in 1822, the YAE underwent alterations.

The Federal Constitution of 1824 (Brasil, 1824) guaranteed all citizens the right to free education, but the title of citizen was intended only for free people, that is, slaves were excluded. Strelhow (2010, p. 51, our translation), explains the context of YAE in the Imperial period. 
With the departure of the Jesuits from Brazil in 1759, adult education collapsed and the organization and use of education fell under the Empire's responsibility. The identity of Brazilian education was then being marked by the elitism that restricted education to the wealthier classes. The royal classes (Latin, Greek, philosophy and rhetoric), an emphasis of Pombaline politics, were specifically designed for the children of Portuguese colonizers (white and male), thus excluding black and indigenous populations. In this way, the history of Brazilian education was marked by a peculiar situation, which was formal knowledge monopolized by the dominant classes.

For the aforementioned author, in this period between the Empire and the beginning of the Republic, the education of young people and adults was charged with a missionary and charitable principle. Literacy for young people and adults is no longer a right but an act of solidarity.

With the beginning of the 20th century, there was a great social mobilization that aimed to reduce illiteracy rates. Brazil began to consolidate the provision of education and cover various social classes with the intention of teaching reading and writing from 1930 onwards. In 1940, YAE once again went through changes, now with political and pedagogical initiatives and with the emergence of the Educational Campaign for Adolescents and Adults. There was greater attention to the elaboration of teaching materials for the adult public with the intention of offering better quality education and in a non-mandatory way, therefore, only those really interested in learning were sought out in schools.

With the end of the Getúlio Vargas government in 1945 and with the changes in the country's political scenario, YAE faced moments of crisis and criticism. However, it is at this moment that YAE gains prominence and starts to show its importance, as in this period it was sought to fight for education for all.

In 1950, the National Campaign for the Eradication of Illiteracy was carried out. This campaign was a landmark in the discussions on adult education, however, its organizers understood that literacy actions were insufficient and that it was necessary to prioritize the education of children and young people, because for this audience, education would add a difference in their lives.

In 1970, the Brazilian Literacy Movement known as MOBRAL (Portuguese initials) grew throughout the national territory. According to Strelhow (2010, p. 54, our translation), the objective of this program is to make functional literacy and promote continuing education. To the cited author

with this program, literacy was restricted to the apprehension of the ability to read and write, without a contextualized understanding of the signs. Thus, the political sense of Mobral was configured, which sought to make the individual responsible for his situation, disregarding his role of being a producer of culture.

Also during this period were actions such as the Literacy Program and the Total Literacy Program that enabled young people, and those who had not yet mastered reading and writing, to continue their studies.

The period of military government ended in the 1980s, with the beginning of the country's redemocratization process. YAE is undergoing changes once again, this time resulting from the extinction of MOBRAL in 1985. In replacement of MOBRAL, the Educar Foundation was created, with specific literacy purposes and within the competences of the Ministry of Education (MEC). Strelhow (2010, p. 55-56, our translation) explains this period.

With the end of Mobral in 1985, other literacy programs emerged in its place, such as the Educar Foundation, which was specifically linked to the Ministry of Education. Its role was to supervise and monitor, together with the constitutions and secretariats, the investment of resources transferred for the execution of its programs. However, in 1990, with the Collor Government, 
the Educar Foundation was extinguished without any other project being created in its place. From then on, the federal government's absence from literacy projects began. Municipalities start to assume the role of youth and adult education. At the same time, there were many experiences of universities, social movements and non-governmental organizations in relation to education.

With the promulgation of the Federal Constitution of 1988 (Brasil, 1988), the right to education was established for everyone, including those who did not have access to education at their proper age or had their educational process interrupted regardless of age. It was a milestone for the Education of Youth and Adults. According to Leôncio Soares (2001, p. 203, our translation),

this constitutional precept contributed to consolidating the few initiatives then existing within the scope of YAE, undertaken by popular administrations and to reinforcing the need for governments to assume it as a duty of the State. In fact, from 1988 onwards, there was a significant expansion and an institutionalization of public education systems in terms of serving young people and adults who had no access to education.

With the extinction of Fundação Educar in the 1990s, YAE went through difficult times. According to Sabia and Militão (2010, p. 4, our translation),

the recommendations of the World Bank, in relation to the Education of Youth and Adults, seem to have been incorporated by the Ministry of Education in its entirety, since, when he took over the Ministry, José Goldemberg, at the beginning of his term, publicly stated that "it is death the social solution to the educational problem of illiterate adults, as they had already learned to survive without schooling" (Haddad \& Di Pierro, 1994, p. 5). Thus, the resources should be destined to young or school-age illiterates to make it possible, in ten years, to eradicate illiteracy. In view of this ministerial perspective, the state commissions of PNAC have progressively stopped acting due to lack of political conditions.

The aforementioned authors also show that in this context of devaluation of youth and adult education, "this modality left the MEC and became the Social Action of the then first lady of the country, Ruth Cardoso, who chaired the Solidarity Community Program" (Sabia \& Militão, 2010, p. 8). Therefore, during the government of President Fernando Henrique Cardoso (FHC), YAE was linked to the Ministry of Social Assistance. At the MEC, programs developed in the form of distance education remained and became increasingly known as the preferred alternative to be practiced as solution to the problems of schooling gaps in the country.

Having to face barriers due to the lack of a federal public policy for YAE, it still suffers from the lack of resources for its maintenance imposed by the Fund for Maintenance and Development of Teaching and Valorization of Teaching (FUNDEF, Portuguese initials). The Fund excluded YAE enrollments in Elementary Education from the calculations for the redistribution of resources per enrolled student linked between government spheres. FUNDEF, Law n. 9,424/1996 (Brasil, 1996) and Decree n. 2,264/1997 (Brasil, 1997) was in force from 1997 to 2006. It was established by Constitutional Amendment n. 14/1996 (Brasil, 1996) as a fundamental instrument of educational reform carried out during FHC's government.

FUNDEF ended up marginalizing Youth and Adult Education. As pointed out by Haddad and Di Pierro (2000, p. 34, authors' highlights, our translation):

given the funding limitations resulting from this measure, the subnational instances of government, which are responsible for the public provision of basic education to the young and adult population, were objectively discouraged from expanding this educational level and modality, which already in 1988 was reflected in the reduction of enrollments. 
In 2003, new perspectives emerged for YAE with the return to MEC during the Lula administration. In the same year, the MEC announces that YAE becomes one of the priorities of the Federal Government, the year in which the Lula government also launches the Literate Brazil Program. According to Haddad (2009), this government promised employment (10 million new jobs), literacy (overcoming illiteracy among young people and adults) and food (zero hunger, three meals a day for everyone), however, at the end of this term, these goals had not been hit.

In terms of employment, its goals were quite far from what was promised at the beginning of the government and the overcoming of illiteracy came up against traditional and inefficient policies, despite the recognition of the right and the return of YAE policies to the direction of the Ministry of Education (Haddad, 2009, p. 360, our translation).

In 2004, another step in favor of YAE was the MEC's initiative to bring together the management of programs to support literacy and elementary education in a new Secretariat for Literacy, Continuing Education and Diversity (SECAD, Portuguese initials). It also instituted a National Commission to consult with municipalities, states and civil society organizations. Later, SECAD started to include the terminology Inclusion and was called SECADI.

As of 2007, Yae was supported by the Fund for the Maintenance and Development of Basic Education and the Valorization of Education Professionals (FUNDEB), under Law n. 11,494/2006 (Brasil, 2006), as it had run out of resources during the duration of the previous fund, FUNDEF.

This new fund brought an advance to YAE by including it as a modality of Basic Education and, thus, EJA started to receive funds for investment/maintenance, which did not occur in the previous fund for ten years. Therefore, FUNDEB meant a guarantee of resources so that municipalities could maintain or open education rooms for young people and adults.

Although YAE was included in FUNDEB, this teaching modality received less value per student compared to regular education. According to Sena (2008), the amount resources per student were $30 \%$ lower compared to regular Elementary Education, in addition to the fact that the FUNDEB law does not establish a minimum application for expenditures in this modality, leaving it to the discretion of each sphere of government (state or municipal) this prioritization of service or not, as the law provided for the indistinct application between stages and modalities. The cited author emphasizes this aspect by stating that

The Fundeb Law provides that the weights, which may fluctuate in a band from 0.7 to 1.3, respecting the minimum scores provided for in its article $36, \S 2$, be fixed based on cost studies carried out by the National Institute of Studies and Educational Research - Inep (article 13, I). However, this sign sinks and is frustrated with the rule of article 21, of Law n. 11,494/07, Fundeb Law, which provides for indistinct application. Weightings are elements for fundraising, but, according to this provision, spending is free, that is, it can be raised in one stage or modality and spent in another (Sena, 2008, p. 325, authors highlights, our translation).

Therefore, we consider inclusion in FUNDEB as an encouragement for YAE, although the effectiveness of the application of resources has been compromised by the non-definition of a mandatory percentage of expenditure in this type of education for state and municipal governments that shared the responsibility for offering YAE. Haddad (2009) emphasizes that there was a clear process of municipalization of YAE in the first stage of Elementary School, with the other levels under the responsibility of the state government, that is, the final years of Elementary School and High School.

We also emphasize the creation of the National Textbook Program for YAE in 2009 (PNLDEJA). According to Cavalcante (2009), the PNLD-EJA had the objective of making textbooks available to students from partner organizations of the Literate Brazil program, from public schools with 
literacy classes, elementary and secondary education classes at YAE. Textbooks would be definitively delivered to students and educators, with no need to return them at the end of the school year.

However, in the last decade, public policies for YAE suffer again its discontinuity and even retreat. Cavalcante (2019, p. 1127, our translation) highlights that from the June 2013 journeys, "a series of instabilities of a legal, administrative, legal, economic and ethical order, but above all political ones affect the YAE modality, indicating its possible disappearance". We explain that the June 2013 journeys were a series of mass mobilizations that took place simultaneously in more than 500 cities across the country. The protests were initially against the increase in public transport fares but revealed a general dissatisfaction of the Brazilian population with the political class, corruption and systematic problems in health and education.

One of the main "attacks" on the teaching modality is evidenced in the extinction of SECADI under Decree n. 9,465/2019 (Brasil, 2019) and with it the disappearance of mentions of YAE in the administrative structure of the Ministry of Education.

[...] more than a pure and simple administrative extinction, there is a discursive reorganization with the creation of a Literacy Secretariat composed of three directorates: the Evidence-based Literacy Directorate; the Literacy Strategic Support Board and the Curriculum Development and Literacy Teacher Formation Board. In articles 29 and 32 of the aforementioned decree, which deal with the structure of these boards, Education for Youth and Adults is not mentioned in any passage, and youth and adults appear in only two instances, regarding the exposure of the competences of the Literacy Department, as a public to be served, and not as a specific modality of school attendance (Cavalcante, 2019, p. 1133-1134, our translation).

In view of the context presented, public policies for YAE are at a time of setback, in which the struggles for the right to education of young people and adults need to be resumed, as although the right to education for all has been contemplated in the Federal Constitution of 1988 (Brasil, 1988), the right is not automatically implemented, that is, it needs to be implemented and its fulfillment guaranteed. In this brief historical review, the discontinuity of the educational policy for YAE is evidenced.

We consider it a contradiction for the country to have Paulo Freire as a son with his Adult Literacy Method and all his work recognized worldwide, that is, the author received 35 Doctor Honoris Causa degrees from universities all over the planet and here the public policies for YAE go against the grain of his literacy method and suffer from the discontinuity and devaluation of this type of teaching. In his book Educação como Prática da Liberdade (Education as a Practice of Freedom) (1967), Paulo Freire explains the "Method" of Adult Literacy in a detailed way, historically contextualizing the proposal and exposing its philosophical and political assumptions. In the introduction to this book, Weffort emphasizes the experiences of the method in the city of Angicos, in Rio Grande do Norte. In 1962, 300 rural workers were literate in just 45 days. Training courses for coordinators were held in several state capitals between June 1963 and March 1964. In 1964, 20,000 culture circles were planned for two million illiterate people. According to Weffort, the Military Coup interrupted the work and repressed all the popular mobilization that had already been achieved. Paulo Freire was detained for 70 days and then exiled to Chile. The Mobral program implemented in 1967, mentioned above, was strictly aimed at reading and writing skills. Not only the Mobral program, but the programs mentioned in the 1990s and 2000s distance themselves completely from Freire's proposal to go far beyond reading the word, that is, promoting reading of the world. For the aforementioned author, literacy and awareness go hand in hand, awareness of the real situation experienced by the student must accompany the entire learning process. Teixeira (2019) seeks to explain the meaning of awareness proposed by Freire. 
In a pedagogy as a practice of freedom, the oppressed must become aware as the subject of their historical reality, the discussion of issues related to work and culture are not separate from awareness, as this awareness often means the beginning of the search for a position of fight (Teixeira, 2019, p. 31, our translation)

After this brief historical context, we then present the characterization and history of YAE in the municipality where this research is carried out.

\section{CONTEXTUALIZATION OF THE MUNICIPALITY AND BRIEF HISTORY OF EJA IN MARÍLIA}

Marilia is a Brazilian municipality in the State of São Paulo that is located in the Center-West region, being $443 \mathrm{~km}$ away from the State Capital. Its nomenclature was created through State Law n. 2161, on December 22, 1926, still as a district of Cafelândia. In 1928, Marília ceases to be a district and is elevated to the category of municipality by State Law n. 2320, of December 24, 1928. Its installation was made official on April 4, 1929, the date on which her birthday is commemorated. Therefore, Marília is a relatively new municipality, having turned 92 years old in 2021.

In the 1940s, the city established itself as a development hub in the west of São Paulo, in which there was a great urban and population growth during this period. In the 1970s, there was a new industrial cycle in the city with the installation of new industries, mainly in the food and metallurgical area.

Nowadays (2021), Marília has approximately 50 industries in the food area, being known as the "National Capital of Food". Its population is approximately 240,590 inhabitants according to data from the Brazilian Institute of Geography and Statistics (IBGE, 2020).

Regarding education, the municipality has educational systems that range from Basic Education to Higher Education. The municipal public network has a total of 52 school units distributed among 33 Municipal Schools of Early Childhood Education (EMEI); 03 Municipal Elementary Schools and Kindergarten Education (EMEFEI); 16 Municipal Elementary Schools (EMEF). These units serve approximately 18 thousand students. The municipality also has the "Profa Yvone Gonçalves" Municipal School for Specialized Care (CEMAEE) which provides assistance to students with delayed neuropsychomotor development, disabilities, pervasive developmental disorders, learning difficulties and high abilities/giftedness.

The city also has in its educational structure, 46 state public schools, in addition to 16 private schools. In Higher Education, it has 02 faculties, 01 university center and 03 universities, of which two are public and one private. Also in the municipality, there are schools offering technicalprofessional courses, such as the Professionalizing Center of Marília (CEPROM), State Technical School (ETEC) Antonio Devisate, National Service for Industrial Learning (SENAI), National Service for Commercial Training (SENAC) and the Social Service for Industry (SESI).

As the focus of our study is Youth and Adult Education (YAE), which is a modality of Basic Education, YAE in the early years of Elementary School has been offered in the municipality of Marília since the mid-1940s. According to Venâncio (2011, p. 101, our translation) "Teaching was offered by the state public education system and by philanthropic associations of religious institutions such as the Catholic Church and the Spiritism religion".

In the 1970s, through Municipal Law n. 1794, of March 26, 1971, the municipality signed an agreement with the Brazilian Literacy Movement (MOBRAL, Portuguese initials) created in December 1967, by Law n. 5379 (Brasil, 1967), being linked to the Ministry of Education and Culture (MEC). MOBRAL then had its activities in the city until 1985, the year in which the Educar Foundation, an agency linked to the MEC and responsible for YAE, was dissolved.

As highlighted by Venâncio (2011), the municipality made an attempt by signing an agreement with the Educar Foundation before its extinction, to continue with the YAE offer. The objective was to take over the YAE classrooms previously managed by the extinct MOBRAL. 
However, the agreement was not made effective and most of the YAE classrooms were closed and some were transferred to the state public education system due to the lack of assistance from the Union.

In this way, the initial years of Elementary School at YAE are now under the responsibility of the state public education system until the municipality adheres to the municipalization process of the initial years of Elementary School (1st to 4th year) which took place in 1998. then, the initial years of YAE's Elementary School, which were previously offered, in large part, by the state public education system, began to be offered almost exclusively by the municipality of Marília. According to Venâncio (2011, p. 117, our translation):

The initial years of YAE, under the name of "Supplemental Education", began to be developed, as a responsibility of the municipality, in the same year as the municipalization of elementary education, regulated by Municipal Law n. 4438 of May 21, 1998 (Marília, 1998). In this beginning, according to article n. 02 of the aforementioned law, only four rooms were opened in the early years of YAE, three of them located in the south and one in the north of the city, which together offered only seventy places.

We reiterate that the municipalization of education in Marilia occurred only for the initial years of elementary school, which currently corresponds to the period from 1st to 5th year. Therefore, the municipality was responsible for offering YAE only in the initial years. The second cycle of this teaching, Elementary II, corresponding to the period from 6th to 9th grade, and High School remained under the responsibility of the state public education system.

In the municipality of Marília, we have the State Center for Youth and Adult Education (CEEJA) which, linked to the State Secretary of Education, has operated in the municipality of Marilia since 1980 and serves the final years of Elementary and High School. The municipality also has four prisons, linked to the state public education system, which offer the modality of Youth and Adult Education for citizens who are in a situation of deprivation of liberty. According to Souza (2018, p. 13-14, our translation),

in Padre Nóbrega, District of Marília, the Penitentiary works linked to E.E. Father João Walfredo Rothermund, who works with students in the closed and semi-open regime. Also, in Nóbrega, the Resocialization Center is linked to E.E. Oracina Corrêa de Moraes Rodine. [...]

In the municipality of Álvaro de Carvalho, the Valentim Alves da Silva Penitentiary works only in a closed regime and is linked to E.E. Rafael Paes de Barros.

In this unit, young and adult students receive the YAE Elementary School - Initial Years, Final Years and High School, in a blended format. [...]

CASA Foundation of Marília - Center for Social and Educational Assistance for Adolescents - is linked to E.E. Monsignor Beaked. All these prison units are part of the Education Program in Prisons, PEB, and receive specific teaching material for YAE or elementary school II and high school. In the case of Elementary School I, the teachers themselves prepare the material.

Based on the information presented by the cited authors, we can observe the low number of schools that offer the YAE modality in relation to the proportion of existing school units in the city of Marilia and which could provide better coverage to the YAE public. We understand that the scarcity of supply of this follow-up does not favor access to YAE students, and that this aspect favors school dropout even more, as the distance between home and school makes it difficult for students who spend more time commuting to stay, among other relevant aspects for the effective attendance of this teaching modality. From this, we discuss in the next section about the provision of YAE in Marilia and the curricula used by educational networks that offer this type of education. 


\section{YAE'S OFFER IN THE MUNICIPALITY OF MARÍLIA AND THE CURRICULUM USED IN THE SURVEYED SCHOOLS}

A study carried out by Lira (2019) showed that in the year 2000 there were in the municipality of Marilia, 08 schools that offered the 1st cycle of Elementary Education for YAE. According to the Municipal Education Plan of Marília (2015-2025), and in accordance with Law n. 7824, of June 23, 2015, in 2015, there were 05 school institutions offering the same segment for YAE (Marília, 2015). In 2017, the municipality had 04 schools that offered the initial years of Elementary School for YAE, with these schools being located in one school in the south zone, one in the west zone and two in the north zone. In 2018, there was a reorganization of the rooms so that the unit in the west zone would no longer serve this type of teaching.

Currently, the YAE teaching modality for the segment of the early years of Elementary School is offered only in three schools in the municipality of Marilia: the Municipal Elementary School (EMEF) Professor Olímpio Cruz, located in the north, the (EMEF) Nivando Mariano dos Santos, located in the south zone, and Antônio Garcia Egéa Municipal Elementary and Early Childhood Education School (EMEFEI), located in Amadeu Amaral, a district in the municipality of Marília.

The offer of the first years of Elementary School for YAE by the municipality takes place in person from Monday to Friday at night.

In relation to the second cycle of Elementary Education for YAE, that is, Elementary Education II, the responsibility for the offer lies with the state public education system, under the coordination of the Board of Education of the Region of Marilia.

YAE is offered for Elementary School II, that is, the final years of Elementary School (6th to 9th grade), at the Antônio Augusto Netto State School, located in the south of Marilia and at the State Center for Youth and Adult Education (CEEJA, Portuguese initials) - Prof. Sebastiana Ulian Pessine, located in the center of the municipality. In addition to the final years of Elementary School, the State Center also offers YAE for High School. CEEJA offers flexible hours (morning, afternoon and evening) and individualized service. The fact that the timetable is flexible is of great value, as the student can study by adjusting their timetable as their routine allows, in addition to the modality being blended, which means that the student can study at home or anywhere else. Another important factor is the individualized service, in which the student can resolve their doubts directly with the teacher who will guide them according to their needs, in the learning processes.

In addition to YAE's public offering by the municipal and state education systems, the municipality has a private offering by Bradesco Foundation, located in the north of the city. Bradesco Foundation offers YAE for the final years of Elementary School and High School. Although it also offers flexible hours, has only one monitor to attend all subjects, students have a period of six months to prepare for the procedural assessments by knowledge area and the final assessment that is scheduled by the institution.

In relation to the curricula used in the schools surveyed, we inform that the Pedagogical Political Projects (PPP) of two Municipal Elementary Schools were verified, one in the north and the other in the south of Marilia, that offer the initial years of elementary school for YAE in the city of Marilia ${ }^{1}$.

The EMEF located in the southern part of the municipality of Marilia, was inaugurated in 2004 , offering Elementary School - initial years (1st to 5th year of regular education) starting to offer the YAE teaching modality in 2007. From the analysis of the PPP for the 2020 academic year, it was possible to observe that its elaboration is based on: The Federal Constitution of 1988 (Brasil, 1988);

\footnotetext{
${ }^{1}$ To obtain the PPP, we contacted the managers by telephone, sent the research project by e-mail and requested authorization for the research and subsequent submission of the PPP. The project provided for the analysis of the two municipal schools and the CEEJA. However, CEEJA ended up not sending the PPP within the requested deadline and we only obtained it from the municipal schools.
} 
the Statute of Children and Adolescents - Law n. 8,069/1990 (Brazil, 1990); The Law of Guidelines and Bases of National Education - Law n. 9394/1996 (Brasil, 1996); The National Policy on Special Education from the perspective of Inclusive Education (Brasil, 2008); the Municipal Education Plan of Marília and the Curriculum Proposals of the Municipal Education Secretariat of Marília, in line with the National Common Curricular Base (BNCC) (Brasil, 2017, 2018), also relying on theoretical contributions such as studies by Davidov, Mukhina, Vygotski, Leontiev and Libano.

The EMEF PPP was designed by a team formed by managers, teachers and employees both new to the team and veterans in the school, aiming that their school activities were "participatory, reflective and based on the real needs and possibilities of the school unit, detected from data collected in the community". The PPP follows the principles of Historical-Cultural Theory.

Although one of the general objectives of the school is "To propose the multidisciplinary teaching of the fields of knowledge in practices and more comprehensive pedagogical projects interrelated to guaranteeing comprehensive, contextualized and meaningful knowledge to learners", the pedagogical matters that are incumbent on YAE are made available in the annexes section of the PPP (Political Pedagogical Project EMEF Nivando Mariano dos Santos, 2020, p. 38, our translation).

Regarding $\mathrm{YAE}$, the teaching modality seems to be treated differently from regular education, almost as if it were a separate "box", because of the 25 projects in the school, only in 01 of them YAE is covered and of the 03 projects in partnership with the Municipal Department of Education in none of them, YAE is included. Its Teaching Plan for the early years of Elementary School is organized in cycles I, II, III and IV, which includes the areas of knowledge: Portuguese Language; Math; Studies of Society and Nature and Art. We did not identify much difference or innovation in the presented content or work methodology and activities developed between the cycles.

The EMEF located in the northern part of the municipality of Marilia, was inaugurated in 1998. Elementary School is offered (1st to 5th year of regular education) and, in 1999, it started to offer the YAE teaching modality. The School's Political Pedagogical Project is built every four years. Only the Management Plan is presented annually. The current PPP was built in 2019, entered into force in 2020 and will be reviewed again in 2024.

The following aspects are worked on at the school: characterization of the community and the school environment, situational, doctrinal and operational frameworks, as well as priority objectives and goals. As mentioned in the 2020 Management Plan, the current school director did not participate in the construction of the PPP carried out in the previous year (2019), as he was managing another school.

Observing the document, it is clear that it is anchored in the Historical-Cultural Theory, as linguistic and theoretical elements grounded in Vygotski are presented throughout the text, a psychologist concerned with the issue of the child's full development, as well as the educator, Paulo Freire, who was also referenced. The YAE Teaching Plan contained in the 2020 Management Plan comprises the areas of knowledge in Portuguese Language, Mathematics, Society and Nature Studies, which are divided into two modules, term I and term II. As we evidenced, there is not much difference or innovation in the presented contents or work methodology and activities developed in the initial years of regular Elementary School. We also emphasize that YAE is not mentioned in any of the projects worked on at the school this year.

In the next section, we present the goals of the National Plans (2014-2024) and Municipal Plans for Education (2015-2025) and enrollment data (2009-2019) that were obtained from the documents Sinopses Estatísticas (statistical synopsis) from INEP. 


\section{YAE IN PNE (2014-2024) AND SME (2015-2025) AND ENROLLMENTS (2009-2019)}

In this section we present the YAE goals both in the National Education Plan PNE (2014 2024), Law n. 13,005 of June 25, 2014 (Brasil, 2014), as of the Municipal Education Plan (2015-2025), Law n. 7824, of June 23, 2015 (Marília, 2015). We tried to compare them with the enrollment data available at the National Institute of Educational Studies and Research Anísio Teixeira over a tenyear period (2009 to 2019), and the illiteracy rate in the municipality obtained from the Brazilian Institute of Geography and Statistics (IBGE, 2010).

In the PNE (2014-2024), we present three goals related to the Youth and Adult Education modality.

\section{Goal 8}

Raise the average schooling of young people and adults between 18 (eighteen) to 29 (twentynine) years of age, in order to achieve at least 12 (twelve) years of study in the last year of the Plan's effectiveness, for the populations from the countryside, from the region with the lowest level of education in the country, and from the poorest $25 \%$ (twenty-five percent), and to equal the average education level among blacks and non-blacks declared to the Brazilian Institute of Geography and Statistics - IBGE.

Goal 9

Raise the literacy rate of the population aged 15 (fifteen) or older to 93.5\% (ninety-three and five tenths percent) by 2015 and, by the end of the term of this PNE, eradicate absolute illiteracy and reduce by $50 \%$ (fifty percent) the functional illiteracy rate.

Goal 10

Offer at least $25 \%$ (twenty-five percent) of youth and adult education enrollments, in primary and secondary education, in an integrated manner with professional education (Brasil, 2014, our translation).

When we identified the goals of the PNE (2014-2024), we observed that they are ambitious and need substantial investments for their realization in the YAE modality. In addition to the aspect mentioned about the FUNDEB Law (Law 11,494/2007) which does not require a minimum percentage of expenditure on the teaching modality by municipal and/or state governments, the approval of Constitutional Amendment 95/2016 (Brasil, 2016) (Proposal of Constitutional Amendment - PEC of the text of public expenditures) which froze public investments in social areas for twenty years and that directly impact on resources destined for education.

According to the Statistical Synopsis of the National Institute of Educational Studies and Research Anísio Teixeira (INEP), in the ten-year period (2009-2019), total enrollments in Brazil in the YAE teaching modality decreased. In 2009, they totaled 4,701,245 enrollments and, in 2019, they accounted for a total of $3,273,668$. Therefore, we had a drop of $30.36 \%$ in YAE enrollments in Brazil in the last ten years. In the State of São Paulo, total YAE enrollments in 2009 were 800,927 and in 2019 they totaled 417,752, that is, a drop of $47.84 \%$ (Brasil, 2009, 2019).

Regarding the Municipal Education Plan (PME) of the municipality of Marilia, Law 7824/2015 (Marília, 2015) establishes 20 goals/objectives related to YAE, among these goals we highlight:

1. ensure the free offer of youth and adult education to everyone who had access to basic education at their own age; [and so on in $2,3, \ldots$ ];

2. eradicate absolute illiteracy by the end of the Plan (2025);

3. reduce the functional illiteracy rate to $8.2 \%$ by 2025 .

4. carry out a diagnosis of young people and adults with incomplete primary and secondary education, to identify the active demand for vacancies in youth and adult education; [...] 
8. carry out regular public calls for education for young people and adults, with dissemination in the media, promoting an active search in collaboration between federated entities and in partnership with civil society organizations;

9. carry out assessment, through specific exams that allow the assessment of the literacy level of young people and adults over 15 (fifteen) years of age;

10. perform actions to assist students in youth and adult education through programs:

- transportation for students with special educational needs - SENs;

- $50 \%$ discount on the value of municipal public transport established by Law;

- offer lunch that meets the nutritional needs of the YAE public;

- establish partnerships with health services for the diagnosis of ophthalmology and pathologies associated with the aging process, seeking to prioritize the care of this public and maintenance of health. [...]

15. consider, in public policies for young people and adults, the needs of the elderly, as well as those of the disabled, with a view to promoting policies for the eradication of illiteracy, access to educational technologies and recreational, cultural and sports activities, the implementation of programs for appreciation and sharing and experience of the elderly and the inclusion of the themes of aging and old age in schools; [...]

20. identify reasons for absenteeism and collaborate with the State to guarantee attendance and support for learning, in order to encourage the expansion of service for these students in the regular public school system (Marília, 2015, p. 143-145, our translation).

In addition to the goals for $\mathrm{YAE}$, we highlight part of the document that also mentions the absolute and functional illiteracy rate in the municipality:

Marilia has 216,745 inhabitants, according to the 2010 IBGE Census, with an illiteracy rate of $4.1 \%$ of the population aged 15 or over, while the functional illiteracy rate is $16.4 \%$. [...] there is a need for the municipality to continue to offer this type of education that is fraught with complexities. [...] According to a diagnosis of the literacy index, a large part of the illiterate population is in the age group above 60 years and presents many challenges. [...] (Marília, 2015, p. 130,132 , our translation).

According to IBGE (2010) data from the municipality of Marília mentioned in the PME (20152025), this had a total of 7,060 people over 15 years of age who could not read and write. Data from the Statistical Synopsis document (2010) by INEP, in the same year, indicate that there were 3,660 enrollments in the city, 1,484 in Elementary School and 2,176 in High School. Based on the analyzed data, there were still 3,400 people over the age of 15 who were still illiterate. We can ask ourselves: where were these people? Why were not they included in YAE enrollments? Did these people lack interest or was there an active search by the municipality to reach this portion of the population?

If we consider the functional illiterates, that is, those who "even knowing how to write simple sentences, do not have the necessary skills to meet the demands of daily life, as well as continue learning and developing throughout life" (Marília, 2015, p. 129, our translation), we will have a much larger number of people who need YAE, based on the $16.4 \%$ of the population in 2010, approximately 34,896 people.

This mismatch between the estimated demand for the modality and school coverage by the studied municipality is presented in a study on the state of São Paulo. According to Cassio et al. (2015, our translation)

although the absolute illiteracy rate at the state level tends to decline and is below the national average (3.7\% in 2013), the average schooling of the São Paulo population is low -9.63 years of study in the average of the population between 15 and 64 years old, according to Seade (2016). According to the 2010 Demographic Census (IBGE, 2011), of the more than 32 million São Paulo citizens aged 15 or over, $37 \%$ had not completed elementary school; and, among 
people aged 18 or over (which totaled, in 2010, nearly 19 million in the entire state), more than 5 million had not completed high school. Therefore, the potential demand for basic education for young people and adults in the state totaled, in that year, almost 17 million people from São Paulo, and the school coverage estimated by Di Pierro $(2014$, p. 50 ) was less than $10 \%$.

Making a parallel between São Paulo data and data on YAE enrollments in Marília in 2010, the estimated demand in this municipality represented less than $10 \%$ of school coverage. We reiterate that, despite IBGE data on illiteracy in the municipality showing a substantial demand for this type of education, we present, in contrast, Table 1 with the number of enrollments in YAE in Elementary and Secondary Education offered by the state and municipal public networks and by the private school system in Marília, covering a period of ten years (2009-2019). We emphasize that there was no offer in the period by the federal public network.

Table 1. List of YAE enrollments in Marília from 2009 to 2019.

\begin{tabular}{|c|c|c|c|c|c|c|c|c|c|c|c|}
\hline \multicolumn{12}{|c|}{ Number of youth and adult education (EJA) enrollments } \\
\hline \multicolumn{6}{|c|}{ Elementary school } & \multicolumn{6}{|c|}{ High school } \\
\hline 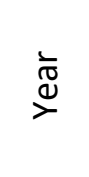 & $\begin{array}{l}\bar{\pi} \\
\stackrel{0}{0} \\
-\end{array}$ & $\begin{array}{l}\overline{\frac{\pi}{0}} \\
\frac{0}{0} \\
\frac{d}{4}\end{array}$ & \begin{tabular}{l}
$\stackrel{ \pm}{ \pm}$ \\
\multirow{n}{*}{}
\end{tabular} & 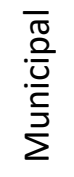 & 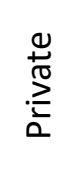 & $\begin{array}{l}\bar{\pi} \\
\stackrel{0}{0} \\
\square\end{array}$ & $\begin{array}{l}\overline{\frac{\pi}{0}} \\
\frac{\tilde{d}}{0} \\
\frac{\Phi}{4}\end{array}$ & \begin{tabular}{l}
$\stackrel{ \pm}{ \pm}$ \\
\multirow{n}{*}{}
\end{tabular} & 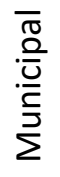 & 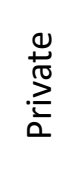 & $T$ \\
\hline 2009 & 2.414 & - & 1.981 & 373 & 60 & 3.702 & - & 3.668 & - & 34 & 6.116 \\
\hline 2010 & 1.484 & - & 1.096 & 326 & 62 & 2.176 & - & 2.087 & - & 89 & 3.660 \\
\hline 2011 & 1.099 & - & 846 & 251 & 2 & 967 & - & 967 & - & - & 2.066 \\
\hline 2012 & 844 & - & 697 & 147 & - & 1.023 & - & 1.023 & - & - & 1.867 \\
\hline 2013 & 933 & - & 768 & 165 & - & 1.639 & - & 1.639 & - & - & 2.572 \\
\hline 2014 & 1.027 & - & 887 & 140 & - & 2.057 & - & 2057 & - & - & 3.084 \\
\hline 2015 & 1.166 & - & 743 & 133 & 290 & 1.988 & - & 1.543 & - & 445 & 3.154 \\
\hline 2016 & 1.081 & - & 826 & 160 & 95 & 2.034 & - & 1890 & - & 144 & 3.115 \\
\hline 2017 & 1048 & - & 852 & 143 & 53 & 2.068 & - & 1.962 & - & 106 & 3.116 \\
\hline 2018 & 909 & - & 745 & 93 & 71 & 1.622 & - & 1.536 & - & 86 & 2.531 \\
\hline 2019 & 697 & - & 546 & 79 & 72 & 139 & - & 1.299 & - & 94 & 2.090 \\
\hline
\end{tabular}

$\mathrm{T}=$ Total number of Youth and Adult Education (EJA) enrollments including Elementary and High School. SOURCE: Instituto Nacional de Estudos e Pesquisas Educacionais Anísio Teixeira.

From the data in Table 1, we can observe that total enrollments in the Youth and Adult Education modality had a drop of $65.82 \%$ between $2009(6,116)$ and $2019(2,090)$. When we separate YAE enrollments from Elementary School and High School, we identified that there was a drop in Elementary School enrollments offered by the state public education network of $72.43 \%$, that is, in 2009 (1981) and in 2019 (546). Likewise, there was a drop in enrollments in Elementary School offered by the municipal public education network of $78.82 \%$, that is, in 2009 (373) and in 2019 (79). In high school, the drop in enrollments offered by the state public education system was 64.59\%. Enrollments in the private education network increased 20\% between 2009 and 2019 in Elementary School and increased 176\% in High School (Brasil, 2009, 2019). 
Table 2. Color/race data of illiterates in Marília (IBGE data regarding the year of 2010).

\begin{tabular}{cc}
\hline Color or race & People aged 15 and older who cannot read and write \\
\hline Asian & 124 \\
White & 3.443 \\
Indigenous & 25 \\
Parda* & 2.815 \\
Black & 653 \\
Total & 7.060
\end{tabular}

*Portuguese word meaning race/colour category that encompasses various shades of brown.

Source: https://cidades.ibge.gov.br/brasil/sp/marilia/pesquisa/23/25124

The latest available data are from the 2010 Census carried out by the IBGE, as in 2020 and 2021, due to budget cuts, it was not possible to carry out the new Census by the agency. Table 2 shows the color/race of illiterate people in the municipality of Marilia this year. The predominant color was white, with $48 \%$ of the illiterate, followed by $39.87 \%$ brown, $9.24 \%$ black, $1.75 \%$ yellow and $032 \%$ indigenous.

From what we can apprehend from the goals for the modality in the PNE (2014-2024) and PMEs (2015-2025) and the decreasing number of enrollments in the last ten years in the country, in the State of São Paulo and in the municipality of Marilia, there is a significant mismatch between what was planned and what was done. YAE faces numerous challenges and constant difficulties in seeking to establish itself as a teaching modality and to enforce its educational rights. The absence of public policies for YAE is easily identified by the lack of investment in offering this segment for quality education. In other words, YAE is the first to suffer from the closing of units, cuts, reduction of classrooms, among other factors that make it difficult or impossible to access education for the young and adult population.

We often see the offer of YAE being carried out only at night, as we can see in the schools surveyed in the city of Marilia. This fact, together with the location of the schools, which, in short, are in distant neighborhoods, hinder student access, which also makes it difficult to prospect for future students, since they depend on public transport. In the PME (2015-2025), the municipality of Marilia informs that it will pay $50 \%$ of the value of the public transport pass, therefore, students will have to pay $50 \%$ of the value. Students who work night shifts need a more flexible study schedule that can meet their demands.

Another point that deserves to be highlighted is the fact that there is no public tender in the studied municipality for teachers to work in YAE. Interested parties provide a selection process that takes place annually, and when taking an YAE class, this journey is classified as an extra class or "double", causing a turnover of teachers in YAE classes, an aspect that makes it difficult for the student to adapt with annual exchanges of teachers. The student ends up taking more time to achieve the learning results, especially in the higher age group (age), which is the profile of the studied municipality.

The lack of specific competition for the teacher to work in YAE reinforces the mistaken idea that it is not necessary for this teacher to have specific formation to work in this teaching segment. It brings as a consequence inadequate curricula and practices where many of the students are stagnant, do not evolve in their educational process. Therefore, what they learn often does not make sense at school and beyond.

What happens with the schools in which the curricula were analyzed is that both bring in their teaching plan repetitive content and an inappropriate methodology for their target audience, which are mostly made up of adults and seniors. In this way, we can analyze, for example, the curricular component of Society and Nature Studies. In the school in the north zone, which brings reproduction content to term II students, which could be replaced by health-related content such as diabetes, hypertension, among others, providing information on how these diseases arise and 
act in the body and forms to avoid or control them by bringing them information about healthy habits and foods. Are these questions that are present in the daily lives of these students and the methodology used, as well as debates and discussions, how does the municipality or school's curriculum proposal bring? It could also include lectures with health professionals for a better understanding of the students.

Another example that we can point out, is based on the curricular proposal of the school in the south, where we can observe that in the Portuguese Language curricular component, contents such as oral reading, reading and production of various textual genres, and conversation wheel, are applied so much for terms I and II as well as for terms III and IV, also maintaining the same methodology in the activities. Newspapers, menus, letters and medicine inserts are elements that are present in the daily lives of these students, which makes it easier to differentiate and perceive the social use of each of these genres, students of terms III and IV would already be familiar with it and repetition of this content could stagnate their learning process.

Another aspect that directly influences the schooling of these students is the fact that they are in multigrade classrooms, where each student is at a different level of learning, needing different attention and having a single teacher to manage this classroom. It happens that many of the students end up being harmed, staying longer than estimated in the classroom, which will demand greater time and the opposite of what is expected ends up happening, there are cuts and reduction in the supply of YAE.

The authors Friedrich et al. (2010, p. 406, our translation) call these aspects evidenced in our analysis as empty pedagogical proposal because they do not contemplate the expectations of students in this modality.

With a specific audience that brings with them sequels of frustrated experiences throughout life, the adult arrives at YAE with a diversified cultural background, countless skills, accumulated knowledge and reflections about their world. Many find themselves humiliated by the condition of being excluded from school for different reasons: need for work, successive failures, for not having adapted to school norms, for not being able to learn what they urgently need to learn what is necessary to survive in this scientific and technological world in which they live. They arrive and find the same school that excluded them years ago with pedagogical proposals that do not contemplate their expectations and schools with specific and generalized rules. This, in addition to other aspects, leads to the high dropout rate observed in YAE programs today. This failure can be explained, mainly, by problems of epistemological and pedagogical conception between what was conceived by the official proposals and what was experienced by this community in the school environment (authors' highlights).

In this sense, we understand the complexity of serving YAE's target audience who have specific demands for their life trajectory. We reiterate, however, "that the purpose of the school encompasses other dimensions of human formation that go beyond the cognitive dimension" (Sabia \& Sordi, 2020, p. 130, our translation)

\section{FINAL CONSIDERATIONS}

As evidenced in our study, the studied municipality has been substantially decreasing the number of enrollments in the YAE modality in the period between 2019-2019 and, also, the number of schools that offer YAE. This drop also happens at the national and state level. In the city of São Paulo, the study by authors Catelli Junior, Di Pierro and Girotto $(2019$, p. 463) show that "the limitation in the number of schools that offer YAE makes it difficult for young people and working adults and family parents to be able to move in the urban space between work, school and home". For the aforementioned authors, if there is no school close to home or work, access is limited and 
permanence becomes difficult, causing a reduction in YAE enrollments. They also claim that the possible causes of the reduction are due to the inadequacy of the offer in terms of location and the availability of means of transport, the inadequacy of school hours in relation to the availability of young people and adults to attend. They also highlight the problems related to the relevance of the curricular or pedagogical proposal and the demand management strategy on the part of the Regional Education Board and the school itself.

We believe that the aspects pointed out by the authors are good indications for further research that can contribute to the implementation of public policies for YAE in the studied municipality that primarily meet the needs of students.

We reiterate the need to continue the struggle for the education of all Brazilians, which must be guaranteed as determined by our 1988 Constitution. We also emphasize that, as Sérgio Haddad teaches us, education is a right of synthesis, that is, it is based on it that citizens will understand about the other social rights they have. Therefore, denying education implies denying access to other rights for Brazilian citizens.

Authors' Contributions: Gonçalves, T. S.: conception and design, acquisition of data, analysis and interpretation of data, drafting the article, critical review of important intellectual content; Sabia, C. P. P.: conception and design, acquisition of data, analysis and interpretation of data, drafting the article, critical review of important intellectual content. All authors have read and approved the final version of the manuscript.

Ethics Approval: Not applicable.

Acknowledgments: Not applicable.

\section{REFERENCES}

Brasil. Constituição da República Federativa do Brasil de 1988. Available at:

http://www.planalto.gov.br/ccivil 03/constituicao/constituicaocompilado.htm

Brasil. Lei no 8.069, de 13 de julho de 1990. Dispõe sobre o estatuto da criança e do adolescente e dá outras providências. Available at: http://www.planalto.gov.br/ccivil 03/leis/L8069.htm

Brasil. Emenda Constitucional no 14, de 12 de setembro de 1996. Modifica os artigos 34, 208, 211 e 212 da Constituição Federal, e dá nova redação ao artigo 60 do Ato das Disposições Constitucionais Transitórias. Available at: http://portal.mec.gov.br/arquivos/pdf/e1496.pdf

Brasil. Lei no 9.394, de 20 de dezembro de 1996. Estabelece as Diretrizes e Bases da Educação Nacional. Available at: http://www.planalto.gov.br/ccivil_03/leis/L9394.htm

Brasil. MEC. Resolução CNE/CEB no 1, de 5 de julho de 2000. Estabelece as Diretrizes Curriculares Nacionais para a Educação de Jovens e Adultos. Available at: http://portal.mec.gov.br/CNE/arquivos/pdf/CEB012000.pdf

Brasil. Lei 11.494, de 20 de junho de 2007. Regulamenta o Fundo de Manutenção e Desenvolvimento da Educação Básica e de Valorização dos Profissionais da Educação - FUNDEB. Available at: http://www.planalto.gov.br/ccivil 03/ ato2007-2010/2007/lei//11494.htm

Brasil. Lei no 13.005, de 25 de junho de 2014. Aprova o Plano Nacional de Educação - PNE e dá outras providências. Available at: http://www.planalto.gov.br/ccivil 03/ ato2011-2014/2014/lei/l13005.htm

Brasil. INEP. Sinopse Estatística (2009 a 2019). Available at: http://inep.gov.br/sinopses-estatisticas-da-educacao$\underline{\text { basica }}$

Catelli Junior, R., Di Pierro, M.C., \& Girotto, E.D. A Política Paulistana de EJA: territórios e desigualdades. Estudos em Avaliação Educacional. São Paulo, v.30, n.74, p.454-484, maio/ago.2019.

Cavalcante, J. Educação de Jovens e Adultos na ordem pós-democrática: desaparecimento da modalidade e invisibilidade institucional. E-Curriculum. São Paulo: v17, n3, p.1123-1143, jul./set. 2019.

Cássio, L.F., Crochic, L., Di Pierro; M.C., \& Stoco, S. Demanda Social, Planejamento e Direito à Educação Básica: uma análise da Rede Estadual Paulista na transição 2015-2016. Educação \& Sociedade, v.37, n.137, p.1089-1119, out./dez., 2016. 
Freire, P. (1967). Educação como Prática da Liberdade. Rio de Janeiro: Paz e Terra, 1997.

Friedrich, M., Canavarro Benite, A.M., Machado Benite, C.R., \& Pereira, V.S. Trajetória de escolarização de jovens e adultos no Brasil: de plataformas de governo a propostas pedagógicas esvaziadas. Ensaio, Rio de Janeiro, v.18, n.67, p.389-410, abr./jun., 2010.

Haddad, S. A participação da sociedade civil brasileira na educação de Jovens e Adultos e na CONFINTEA VI. Revista Brasileira de Educação, Rio de Janeiro, v.14, n. 41, p. 355-369, maio/ago.2009

Haddad, S., \& Di Pierro, M.C. Diretrizes de política nacional de educação de jovens e adultos: consolidação de documentos 1985/1994. São Paulo: CEDI, Ação Educativa, 1994.

Haddad, S., \& Di Pierro, M.C. Aprendizagem de Jovens e Adultos - Avaliação da década da educação para todos. São Paulo em Perspectivas. São Paulo, v.14,n.1,p.29-40, mar. 2000

IBGE - Instituto Brasileiro de Geografia e Estatística. Available at: https://cidades.ibge.gov.br/brasil/sp/marilia/pesquisa/23/25124

Lira, D. A. A presença de negros em salas da Educação de Jovens e Adultos nas escolas de Marília: A face pública da exclusão educacional do negro. Monografia (Graduação em Ciências Sociais) Universidade Estadual Paulista Júlio de Mesquita Filho, Marília, 2019

Marília. Lei 6.183, de 11 de janeiro de 2005. Aprova o Plano Municipal de Educação.

Marília. Lei n. 7.824, de 23 de junho de junho de 2015. Aprova o Plano Municipal de Educação. Marília, SP: Secretaria Municipal da Administração, jan. 2005.

Marília. Projeto político pedagógico EMEF Nivando Mariano. 2020.

Marília. Projeto político pedagógico EMEF Olímpio Cruz

Quaglio, P. O Ensino Supletivo: Organização, Problemas e Perspectivas. São Paulo: Revista Didática, v.28, p.73-83, 1992.

Sabia, C.P.P., \& Militão, S.C.N. A Marginalização da Educação de Jovens e Adultos no Contexto Contemporâneo: algumas reflexões. In: 9a Jornada do Núcleo de Ensino de Marília, UNESP, 2010, Marília/SP. Ensino e Aprendizagem como processos humanizadores: propostas da teoria histórico-cultural para a Educação Básica, 2010.

Sabia, C.P.P., \& Sordi, M.R.L. Um olhar para a dimensão infraestrutura como uma das condições objetivas possibilitadoras da qualidade em escolas públicas. Revista Ibero-Americana de Estudos em Educação, Araraquara, v. 16, n. 1, p. 127-152, jan./mar. 2021.

Sena, P.M.A legislação do FUNDEB. Cadernos de Pesquisa. São Paulo, v. 38, n. 134, p.319-340,maio/ago.2008.

Soares, L. J. G. As políticas de EJA e as necessidades de aprendizagens dos Jovens e Adultos. Educação de Jovens e Adultos: novos leitores, novas leituras. In: RIBEIRO, V. M. (org.) Campinas: Mercado de Letras; São Paulo: Ação Educativa, p. 201-224, 2001.

Souza, J.P.F A relação Professor-Aluno e a Produção textual no CEEJA de Marília/SP: uma abordagem dialógica. Tese (Doutorado em Educação). Universidade Estadual Paulista Júlio de Mesquita Filho, Marília, 2018.

Srelhow, T.B. Breve História sobre a Educação de Jovens e Adultos no Brasil. Revista HISTEDBR On Line, Campinas, n.38, p.49-59, jun.2010.

Teixeira, R.F.B. Educação como prática da Liberdade - Dia 1. In: Dickmann, I.; Dickmann, I. (orgs) 365 dias com Paulo Freire. Diálogo Freireano, 2019, p. 31.

Venâncio, J.C. Os anos iniciais da EJA no município de Marília/SP e Presidente Prudente/SP: uma análise das políticas educacionais e suas influências no desenvolvimento das propostas de EJA. Dissertação (mestrado em Educação). Universidade Estadual Paulista Júlio de Mesquita Filho, Presidente Prudente, 2011.

Received: 31 July 2021 | Accepted: 2 November 2021 | Published: 23 December 2021 